\section{Research Opportunities}

\section{Calling all public library experts}

The International Network of Public Libraries was established in 1996 at the initiative of the Bertelsmann Foundation and is currently made up of 11 innovative heads of libraries from 9 countries. It pools the know-how that exists worldwide, strengthens the exchange of experience among experts, supports the development of successful management concepts and especially promotes the transfer of know-how into practice. The Foundation wants to expand this group and is therefore looking for five practitioners with outstanding experience and results in innovative library work. Candidates are invited to work on the following subjects:

EFFECTIVE LEADERSHIP: Demands placed on management; structures and methods to secure long term motivation of staff.

\section{PARTNERSHIPS AND COOPERATION:}

Successful partnerships and their integration into the overall concept of the library.

\section{EFFICIENT EMPLOYMENT OF RESOURCES:} Organisation structures and mechanisms that lead to cost-consciousness and to thrifty business management.

\section{NEW DISTRIBUTION CHANNELS - NEW}

SERVICES: Specially tailored offerings and innovative services for new, potential customers.

\section{NEW TECHNOLOGIES: Models for a}

permanent flexibility vis-à-vis technological innovation; formation of the personnel, financial and organisational structure.

For further information contact: Bertelsmann Foundation Public Libraries Division

(Bettina Windau) e-mail:

bettina.windau@bertelsmann.de

http://www.stiftung.bertelsmann.de/english/netzw erk/lib/index.htm

\section{'Successful Co-operation' project}

Among the research projects to be funded through the British Library Research \& Innovation Centre's summer 'Library Co-operation' call was the following. (To access the relevant web page go to http://www.bl.uk and click on "Services", then "Research and Innovation" and then "News and events"http://www.bl.uk/)

Hatrics - the Southern Information Network, and Capital Planning Information Ltd, information \& development consultants, have successfully bid for a major grant from the British Library to carry out research on Library \& Information co-operation over the next year.

The project stems from a recent Call for Tenders by the British Library Research \& Innovation Centre (BLRIC) and is entitled "Successful Cooperation in Library \& Information Services : measuring the economic value of cooperation".

The research will address the following issues :

- the economic value of co-operation: identification and measurement of benefits to the economy of the area covered by the activity, and financial savings to individual partners, as a result of co-operation

- identification of the critical success factors which have featured in Hatrics' 35 years of cooperative activity, and assessment of the extent to which these are axiomatic and/or transferable

- identification of factors, strategies \& policies not found to be productive in Hatrics' experience, and whether these lessons are again axiomatic and/or transferable

- cross-sectoral arrangements and the extent to which diverse users and providers can develop a common purpose and expectations

- the extent to which the future of traditional cooperation will be enhanced or threatened by digital storage \& communications technology 
Research Opportunities Ros Cotton

- the role of regional co-operation in the face of the World Wide Web and electronic delivery of information \& documents from e.g. the British Library

- the impact of recent Local Government Reorganisation on LIS sector networking

The research is being undertaken between December 1997 and January 1999. Project Head will be Bernard Naylor MA ALA, Librarian, University of Southampton and Chairman of Hatrics. Project Director will be Don Kennington FLA FIInfSc, Principal Consultant at Capital Planning Information Ltd.

\section{NHS Regional Librarians Group Research Panel}

\section{NHS RLG \& UMSLG RESEARCH BURSARY 1998}

The NHS Regional Librarians Group (RLG) and the University Medical School Librarians Group (UMSLG) wish to promote a culture within which existing practice and ideas are more frequently challenged. We are awarding a bursary of up to $£ 1,500$ to support a research project in the broad area of health care librarianship and information work.

Applications are invited from practising librarians, students and others throughout the United Kingdom who plan to undertake research in 1998. The project will be assessed on . methodology, innovation, likely practical value and applicability. For example, a study could focus on the information needs of a specific group of health care professionals or of a particular patient group. Comparative studies, costings or modelling studies would also be relevant.

The timetable for the receipt of applications, the decision-making process and the award of the bursary for 1998 is as follows:

Applications should be submitted not later than Friday 17 April 1998

The successful applicant will be notified not later than 10 June 1998

The successful project should submit a report to
Library \& Information Research News (LIRN)

Volume 22 - Number 70 - Spring 1998

the convenor of the RLG Research Panel by

November 1998

The administration of the 1998 bursary is being handled by Judy Palmer, convenor of the

Research Panel of the Regional Librarians Group, who will be happy to give further information and advice and details of the application procedure.

Judy Palmer, Director Health Care Libraries Unit

John Radcliffe Hospital

Oxford OX3 9DU

Tel: 01865221950 Fax: 01865220040

E-mail: HYPERLINK mail

to:judith.palmer@hclu.ox.ac.uk 